DOI https://doi.org/10.30525/978-9934-26-073-5-1-7

\title{
ПРОТИСТАВЛЕННЯ КОМПОНЕНТІВ БОГ / ЛЮДИНА, БОГ / ДИЯВОЛ У СКЛАДІ ПОЛЬСЬКИХ ПАРЕМІЙНИХ ОДИНИЦЬ
}

\author{
Мороз Т. $\mathrm{O}$. \\ аспірантка \\ Інститут мовознавства імені О. О. Потебні \\ Національної академії наук Украӥни \\ м. Київ, Україна
}

Кожна мова багата прислів'ями та приказками. Безсумнівно, їх поява $\epsilon$ універсальним явищем, оскільки вони, маючи багатовікову історію та будучи своєрідним мікросвітом, відображають уявлення про світ, самобутність культури, моральні основи та усе те, що становить духовну спадщину народу. Як відомо, релігія є одним із найважливіших явищ духовної культури будь-якої нації. Релігійні мотиви, символи та образи, їх семантичні особливості знайшли своє відображення саме у паремійних одиницях (далі - ПО).

Об'єктами зацікавлень серед науковців, праці яких присвячені релігійній тематиці, є паремії з компонентами Бог, диявол та людина. Аналіз низки досліджень свідчить про те, що саме образ Бога (концепт Бог) $є$ одним із центральних у семантичній структурі прислів їв та приказок. Особливості відображення компонента Бог у складі паремійних та фразеологічних одиниць на матеріалі різних мов представлено у дослідженнях А. В. Шабан, Ю. В. Жарікової, М. Бойчук, О. І. Черненко, Т. П. Вільчинської, Г. В. Сергієнка; Л.В.Базарової, А. К. Погребняк, О. К. Калькової; Р. Вижкевич-Максимов, М. Ноінської; 3. Ш. Асехманової; Л. Ф. Самигулліної-Касерти та ін. До вищих цінностей належить доля людини, яка іще 3 народження визначена Богом. Про тісний взаємозв'язок Бога та долі йдеться у працях 3. Г. Коцюби, О. Ю. Печьонкіної та ін.

Різноаспектним за семантикою виявився образ диявола - символ зла, пекла. Дослідженням цього образу займалися К. Длугош, К. Ружанська, Е. Скорупська-Рачинська, Я. І. Івченко та ін. Центральними компонентами протиставлення Бог/ диявол зазвичай $€$ категорії моралі - добро та зло. Аналіз цієї опозиції здійснювали Р. Джьвігол і Т. Ю. Передрієнко. 
Мета доповіді - дослідити особливості протиставлення компонентів Бог / людина, Бог / диявол у семантичній структурі польських прислів “їв та приказок.

Серед основних критеріїв, за якими оцінюють людину, є іï ставлення до найвищих цінностей, однією із яких є Бог - надприродна сутність, вища сила. «Містком» між Богом і людиною $\epsilon$ духовність, яка віддзеркалює внутрішній світ людини. На противагу Богу, постає зла сила, злий дух - диявол, який робить усе для того, аби скерувати людину до скоєння гріховних дій та затруїти їй душу.

Проаналізувавши фактичний матеріал, ми зафіксували низку польських прислів'їв та приказок, що представляють опозиції Бог/ людина, Бог / диявол. Протиставлення Бог / людина репрезентують такі варіанти компонентів у польських ПО, як Bóg / czlowiek, Bóg / człek, Bóg / doktor, Pan Bóg / człowiek, Bóg / przyjaciel (król, pan, cesarz), Pan Bóg / chłop, Pan Bóg / gospodarz, Pan Bóg / ludzie, boski / człowieczy. У пареміях з опозицією Бог / диявол найчастіше протиставляються компоненти Bóg / czart, Bóg / szatan, Pan Bóg / diabet.

Група «Бог / людина». Кожна людина 3 народження - духовна істота, з певними релігійними уявленнями. Одначе різниця між людьми полягає у силі віри в Бога та у подальшому виборі віросповідання. Як засвідчує прислів'я Każdy o sobie, a Bóg o wszystkich «кожен про себе, а Бог - про усіх" [Świerczyńska, s. 352] Бог, будучи турботливим, милостивим, дбає про усе, що сотворив, на відміну від людей, які через свою егоїстичність думають лише про себе. Мудрість Божу ілюструє прислів'я Ludzie uczq mówić, a Pan Bóg myśleć «люди вчать говорити, а Господь Бог думати" [NKP, I, s. 174], у якій за допомогою семантично протилежних компонентів ідеться про те, що люди вчать лише говорити, натомість Господь навчає людину мудрості, зокрема мислити. У ПО Bóg same serca widzi, czlowiek tylko podobieństw się chwyta «Бог бачить самі серця, а людина лише схожості хапає" [NKP, I, s. 152] ідеться про те, що Господь бачить внутрішній світ кожної людини, іiі сутність, сама ж людина бачить у кожному лише своє або те, що подібне до свого.

У житті людини відбувається усе не випадково, а лише за Божою волею. Тому варто змиритися з усім та впевнено пройти усі життєві труднощі. Наступні паремії засвідчують всемогутність Бога, що протиставляється безвладності, неспроможності звичайної людини змінити те, що визначив Всевишній: Co Bóg przeznaczy, czlowiek nie przeinaczy «що Бог визначить, людина не переінакшить” [NKP, I, s. 155], Co Bóg przeznaczy, tego żaden doktor nie przeinaczy «що Бог визначить, того жоден лікар не переінакшить" [NKP, I, s. 155], Co Bóg postanowit, 
czlowiek nie odmieni «що Бог вирішив, людина не змінить" [NKP, I, s. 155], Co Bóg w niebie naznaczyt, tego czlowiek zmienić nie może «що Бог у небі запланував, того людина змінити не може" [NKP, I, s. 155], Co Bóg zbudowat, tego ludzie nie zrujnuja «що Бог збудував, того люди не зруйнують" [NKP, I, s. 155]. Сила, міць Господа протиставляється слабкості людини у прислів'ї Czlowiek buduje, Bóg rujnuje «людина будує, а Бог руйнує” [NKP, I, s. 158]. У ПО Co Bóg zlaczyl, to chyba śmierć rozlaczy «що Бог поєднав, то хіба що смерть розлучить" [NKP, I, s. 156] за допомогою семантично протилежних компонентів Bóg złączyt - śmierć rozłaczy наголошується на тому, що розлучити те, що поєднав Господь підвладно лише смерті. У польських пареміях Бог також постає в образі Володаря господарства, від якого залежить урожайність на землі. Людина завдяки своїй праці лише засіває поля, одначе природа підлегла саме Богові, який благословляе землю на щедрі дари. Таку закономірність висвітлено у прислів'ях Czlek sieje, a Bóg rodzi «людина cie, а Бог родить" [NKP, I, s. 158], Czlowiek sieje, Bóg urodzaj daje «людина сіє, а Бог дає врожай” [NKP, I, s. 158].

Прихильність Бога мала велике значення для людини й під час воєн, битв. Здобуття перемоги не залежало лише від зусиль людини. На полі бою усе відбувається так, як визначив Господь. На це вказують протилежні компоненти у пареміях Czlowiek (chtop, żotnież) strzela, a Pan Bóg kule nosi «людина (селянин, солдат) стріляє, а Господь Бог кулі носить" [NKP, I, s. 158], Chtop nosi proch, a Pan Bóg kulki «селянин порох носить, а Господь Бог - кульки" [NKP, I, s. 158].

Група «Бог / диявол. Духовна боротьба між Богом і дияволом представлена як протистояння між двома протилежними силами у прислів'ї Bóg swoje, czart swoje! «Бог своє, а чорт своє” [NKP, III, s. 363]. Бог є втіленням добра, а диявол - зла. Таку думку фіксуємо у ПО Gdzie Pan Bóg sieje przenice, tam diabet kąol «де Господь Бог сіє пшеницю, там диявол - кукіль (диявольську квітку)" [NKP, II, s. 1144], Pan Bóg sieje przenice, a diabet $w$ niq miesza kakolu połowice «Господь Бог сіє пшеницю, а диявол у неї половину куколя додає" [NKP, II, s. 1144]. У прислів'ї Kiedy dziecię ma upaść, to Pan Bóg mu pierzyne podścieta; a kiedy stary ma upaść, to diabel ти bronę podrzuca «коли дитя має впасти, то Господь Бог перину підстеляє, а коли старий має впасти, то диявол борону підкладає” доброта, жалість Господа протиставляється злості, підступності та байдужості диявола [NKP, I, s. 529]. Перед людиною постає вибір: чи бути з Богом, чи обрати гріховний шлях 3 дияволом?. Господь милостивий з усіма людьми, як із добрими, так і зі злими. Але, як бачимо 3 наступних паремій, Бог опікується лише хорошими людьми, а диявол - 
поганими: Bóg daje szczodremu, a diabet skapeти «Бог дає щедрому, а диявол - скупому" [NKP, I, s. 148], Bóg daje hojnemu, a diabet skapemu «Бог дає щедрому, а диявол - скупому" [NKP, I, s. 148]. У ПО Gdzie Pan Bóg palec potoży, tam diabet cata tapę «де Господь Бог палець покладе, там диявол цілу лапу" [NKP, I, s. 161] верховенство Бога протиставляється слабкості диявола. I Бог, і диявол є творцями чогось. Але різниця полягає у тому, що Бог - творець добра, а диявол - зла. Як приклад можна назвати прислів'я Pan Bóg wynalazt jarmarki, a diabet frymarki «Господь Бог винайшов ярмарки, а диявол - торговий обмін (торгівлю за обміном)" [NKP, I, s. 832], Pan Bóg daje kupca, a diabet faktora «Господь Бог дає купця, а диявол - посередника" [NKP, II, s. 251], Kiedy (gdzie) Pan Bóg daje kupca, to diabel zaraz niesie faktora «куди (де) Господь Бог дає купця, то диявол одразу несе посередника" [NKP, II, s. 251].

Отже, опозиції Бог/людина, Бог / диявол є одними з універсальних, які формують релігійну картину світу. Вони яскраво представлені і в структурі польських прислів 'їв та приказок. Аналіз групи «Бог / людина» показав, що Бог зображується всесильним, справедливим, натоміть людина - слабкою, нездатною піти проти Божої волі. Боротьбу двох протилежних сил (добра і зла) представлено у групі «Бог / диявол». У ній вищість Господа, який опікується людьми, є Творцем добра, протиставляється дияволу, який намагається лише зашкодити усьому живому та $є$ втіленням зла.

\section{Література:}

1. NKP - Krzyżanowski J. Nowa księżka przysłów i wyrażeń przysłowiowych polskich : W 4 t. - Warszawa : PIW. - T. I. - 1969. - 881 s.; T. II. $-1970 .-1165$ s.; T. III. $-1972 .-996$ s.

2. Świerczyńska D. Przysłowia są na wszystko. Warszawa: Wydawnictwo Szkolne PWN, 2001. 548 s. 